\title{
GaSb-BASED HETEROSTRUCTURES FOR HIGH POWER AND PULSED LASER OPERATION
}

\author{
J. Paajaste ${ }^{\text {a }}$, S. Suomalainen ${ }^{\text {a }}$, R. Koskinen ${ }^{\text {a }}$, A. Härkönen ${ }^{\text {a }}$, S. Kivistö ${ }^{\text {a }}$, M. Guina ${ }^{\text {a,b }}$, \\ O.G. Okhotnikov ${ }^{a}$, and M. Pessa ${ }^{a}$ \\ ${ }^{a}$ Optoelectronics Research Centre, Tampere University of Technology, P. O. Box 692, FIN-33101 Tampere, Finland \\ E-mail: jonna.paajaste@tut.fi \\ ${ }^{\mathrm{b}}$ RefleKron Ltd, Muotialankuja 5 C 5, FIN-33800 Tampere, Finland
}

Received 26 August 2009; revised 9 February 2010; accepted 19 March 2010

\begin{abstract}
We have studied monolithically grown GaSb-based vertical-cavity heterostructures. First we demonstrate GaSb-based optically pumped vertical-external-cavity surface-emitting laser (OP-VECSEL) emitting multi-watt output power. A VECSEL gain structure comprising $15 \mathrm{In}_{0.2} \mathrm{Ga}_{0.8} \mathrm{Sb}$ quantum wells grown on (100) $n$-doped $\mathrm{GaSb}$ substrate emitted continuous wave output power of over $4 \mathrm{~W}$ at $1970 \mathrm{~nm}$ wavelength operating near room temperature. Lasing was detected even at $50{ }^{\circ} \mathrm{C}$ mount temperature. We also present a GaSb-based semiconductor saturable absorber mirror (SESAM) operating at $2 \mu \mathrm{m}$ wavelength region. For the purpose of generating short laser pulses, the SESAM was carefully designed to attain a large modulation depth. The device was utilised successfully to passively Q-switch a $2 \mu \mathrm{m} \mathrm{Tm}{ }^{3+}-/ \mathrm{Ho}^{3+}$-doped fibre laser, demonstrating record-short Q-switch pulses of about $20 \mathrm{~ns}$.
\end{abstract}

Keywords: molecular beam epitaxy, antimonides, semiconducting III-V materials, infrared devices

PACS: 42.55.Xi, 73.61.Ey, 42.72.Ai

\section{Introduction}

Single-mode lasers operating in the $2-3 \mu \mathrm{m}$ wavelength range are attractive for various sensing and laser spectroscopy applications, and in particular for the detection of atmospheric pollutants [1]. Many gas molecules, like carbon dioxide, have absorption lines in the $2-3 \mu \mathrm{m}$ spectral regions which make environmental sensing possible [2]. Lasers operating at $2-3 \mu \mathrm{m}$ are considered to be promising tools also for remote sensing, free space communication, and micro-surgery [3]. Semiconductor saturable absorber mirrors (SESAMs) for these wavelengths would, for example, allow the development of practical ultrafast Tm- and Ho-doped fibre lasers or passive mode locking of vertical-externalcavity surface-emitting lasers (OP-VECSELs) for ultrashort pulse generation.

High-power, edge-emitting diode lasers based on the (AlGaIn)(AsSb) material system can cover the 2.0 $2.7 \mu \mathrm{m}$ band, but they have a poor-quality elliptical output beam [4]. OP-VECSELs, also known as opticallypumped semiconductor disk lasers (OP-SDLs), provide a good quality, nearly diffraction limited beam, and output power much higher than a single-mode laser diodes (LDs). Moreover, the external cavity configuration en- ables the use of intra-cavity filters for wavelength tuning $[5,6]$. When compared with LDs, OP-VECSELs are more advantageous also in terms of fabrication complexity; there is no need for doping associated with electrical injection [7].

SESAMs are nonlinear optical elements that impose intensity-dependent reflection on a light beam incident upon them. Incident light of low intensity is absorbed, while high intensity light is reflected from the saturable absorber mirror with much less attenuation. This nonlinear behaviour is the key mechanism for passive Q-switching and mode locking of lasers [8]. When compared to other conventional saturable absorbers, advantages of SESAMs are that they can be custom-made for different wavelength ranges and their properties can be tailored for a specific purpose. For instance, to obtain stable, self-starting Q-switching with a SESAM, one key parameter, the modulation depth $\Delta R$, i.e. the difference between high and low intensity reflectivity, can be enhanced in many ways: by (i) increasing the number of quantum wells (QW) or quantum dots (QDs), (ii) placing the absorbing layers at the antinodes of the optical field inside the cavity, (iii) enhancing the finesse of the cavity by increasing the number of top 




Fig. 1. Layer design of the VECSEL structure.

distributive Bragg reflector (DBR) layers, and (iv) designing the cavity thickness for resonant operation in conjunction with the laser operating wavelength.

Although it is possible to extend the operating range of InP-based SESAMs to near $2 \mu \mathrm{m}$, it is not a straightforward approach because there is less flexibility in tailoring the nonlinearity to a specific value; one can use only a few highly strained InP-based quantum wells operating above $1.6 \mu \mathrm{m}$. In addition, it is difficult to find high index contrast materials for highly reflective DBRs that would be lattice matched to InP and have a wide reflectivity band. The GaSb material system enables the use of lattice matched distributed Bragg reflectors (DBRs) for both VECSELs and SESAMs. DBRs comprised of layers with a high refractive index contrast, namely $\mathrm{AlAs}_{0.08} \mathrm{Sb}_{0.92}$ and $\mathrm{GaSb}$, have an exceptionally broad stop-band ( $300 \mathrm{~nm}[5])$ and require a relatively small number of layer pairs to achieve high reflectance. The broad stop-band makes GaSbbased vertical-cavity lasers highly interesting for spectroscopic applications requiring a wide tuning range.

In this study we demonstrate both high power OPVECSELs as well as a highly nonlinear GaSb-based SESAM, which was utilised in a passively Q-switched $\mathrm{Tm}^{3+}-/ \mathrm{Ho}^{3+}$-doped fibre laser. The SESAM's large modulation depth, caused by the nonlinearity, led to short pulse generation.

\section{Fabricated structures}

The semiconductor structures were grown using a conventional solid source molecular beam epitaxy (MBE) reactor. Elemental indium, aluminium, and gallium together with $\mathrm{As}_{4}$ and $\mathrm{Sb}_{4}$ were used as group-III and $-\mathrm{V}$ sources respectively. The group- $\mathrm{V}$ constituents were cracked into $\mathrm{As}_{2}$ and $\mathrm{Sb}_{2}$ using high temperature cracking tubes.

The laser gain mirror structure consists of a DBR and a gain region with multiple QWs. First a GaSb buffer layer was grown on an $n$-doped (100)-oriented $\mathrm{GaSb}$ substrate to smoothen the surface. The buffer

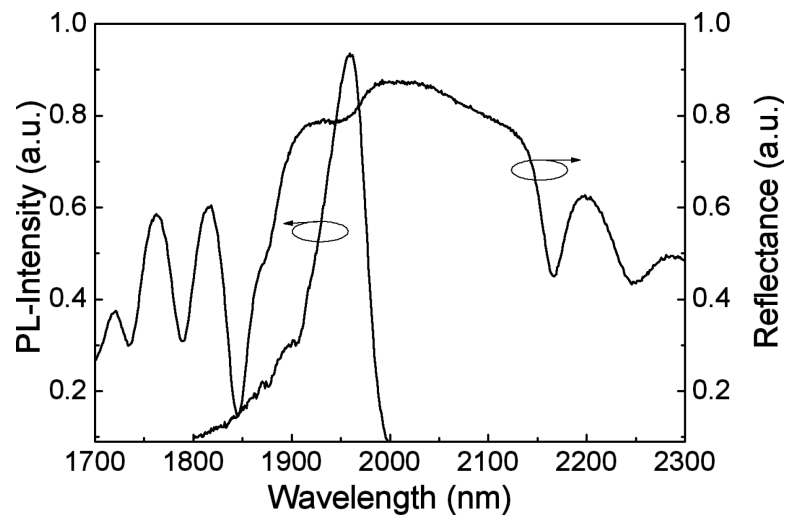

Fig. 2. Room temperature photoluminescence and reflectance spectrum of the VECSEL structure.

was followed by 18.5 pairs of lattice matched $\mathrm{AlAs}_{0.08}$ $\mathrm{Sb}_{0.92} / \mathrm{GaSb}$ layers forming the DBR and the QW active region. The active region for the high-power VECSEL consists of five groups of $\mathrm{In}_{0.2} \mathrm{Ga}_{0.8} \mathrm{Sb} \mathrm{QWs}$, each group containing three quantum wells having a width of $8 \mathrm{~nm}$. The QWs were embedded in GaSb and the structure was closed with a lattice matched $\mathrm{AlAs}_{0.08} \mathrm{Sb}_{0.92}$ window layer to ensure good carrier confinement. The window was followed by a thin $\mathrm{GaSb}$ cap layer to prevent oxidation. The QW groups were located at the antinodes of the standing wave optical field in the 3- $\lambda$ micro-cavity formed by the DBR and the semiconductor-air interface. The VECSEL structure is shown in Fig. 1. The room-temperature photoluminescence (PL) and reflectivity curves for the VECSEL are shown in Fig. 2.

The VECSEL wafer was processed into $2.5 \times 2.5 \mathrm{~mm}^{2}$ gain chips and capillary bonded with water to a type IIa natural diamond heat spreader with $300 \mu \mathrm{m}$ thickness. The diamond allows efficient heat removal from the gain region and avoids the need to conduct thermal energy through a heat resistant DBR [9]. The bonded chip was mounted to a water cooled copper heat sink. The diamond-air interface was antireflection coated to reduce the signal and pump reflection.

The SESAM structure was also grown on an $n$-doped (100)-oriented GaSb substrate and similar to VECSEL 


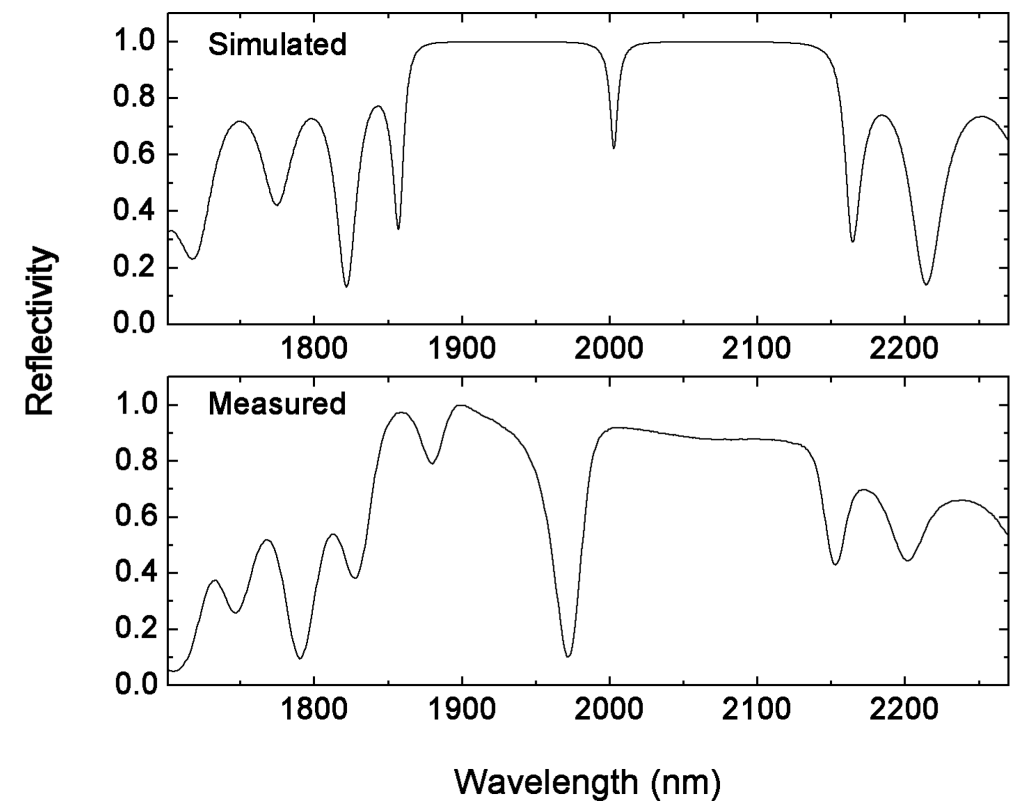

Fig. 3. Simulated and measured reflectance spectra of the SESAM. The high reflectivity band is centred at $2000 \mathrm{~nm}$ with the cavity resonance dip at $1970 \mathrm{~nm}$. The broadness of the high-reflectivity band $(300 \mathrm{~nm})$ is due to high index contrast of GaSb/AlAsSb materials used in the DBRs.

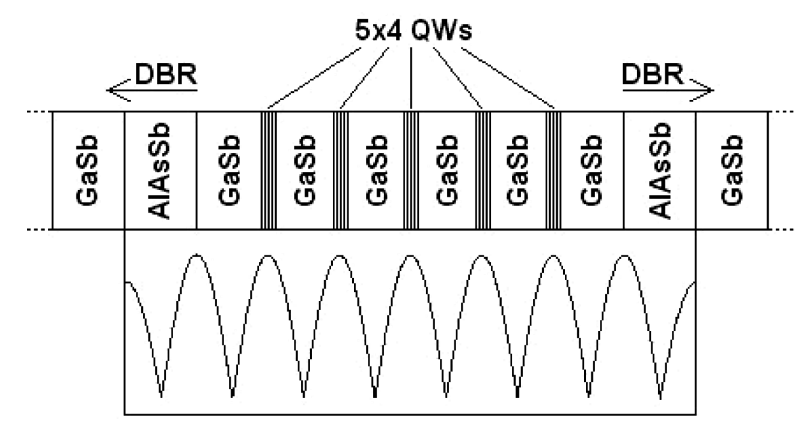

Fig. 4. Layer design of the SESAM structure. The quantum wells are placed at the antinodes of the standing wave optical field $(\lambda=$ $2 \mu \mathrm{m})$ in the cavity defined by the top and bottom DBRs.

a $100 \mathrm{~nm}$ thick GaSb buffer layer was grown first to improve the growth interface for subsequent layers. The buffer layer was followed by the bottom DBR, a QW absorber region, and a top DBR. The SESAM structure was simulated using the Essential Macleod optical coating design software. The simulation showed that 18.5 pairs of $\mathrm{GaSb} / \mathrm{AlAs}_{0.08} \mathrm{Sb}_{0.92}$ for the bottom DBR is sufficient to obtain a reflectivity of over $99.9 \%$ and a stop-band of $300 \mathrm{~nm}$ width. The simulated reflectivity of the SESAM is presented in Fig. 3. The optical thickness of each DBR layer is $500 \mathrm{~nm}$ for a stop-band centred at $2 \mu \mathrm{m}$. A top DBR with four layer pairs was added to enhance the modulation depth of the device. In active region the total number of QWs has been 20 , so that it consists of five groups of four $8 \mathrm{~nm}$ thick $\mathrm{In}_{0.22} \mathrm{Ga}_{0.78} \mathrm{Sb}$ QWs embedded in GaSb. The groups are separated by thick GaSb barriers and positioned at the antinodes of the standing wave optical field in the cavity. Figure 4 shows the active region along with the optical field distribution. The SESAM was designed to be a resonant device - the optical length of the cavity is a multiple of half of the operating wavelength. Operating at a resonant wavelength enables higher nonlinear reflectivity to be achieved, due to an increased effective interaction length between the optical field and the QWs.

\section{Experimental results and discussion: VECSEL}

The VECSEL gain chip was measured using a V-shaped laser cavity configuration consisting of the mounted gain chip, a highly reflective folding mirror with a radius of curvature of $200 \mathrm{~mm}$, and a partially reflective planar output coupler (OC). The pump source used was a $980 \mathrm{~nm}$ fibre coupled multimode diode laser. The pump beam was focused onto the sample to a spot of about $290 \mu \mathrm{m}$ in diameter. The laser schematic is presented in Fig. 5. VECSEL was operated with a $2 \%$ transmissive output coupler. It exhibited excellent temperature behaviour. The output power was over $4 \mathrm{~W}$ at $15^{\circ} \mathrm{C}$, and still $3.6 \mathrm{~W}$ at room temperature at a wavelength of $1970 \mathrm{~nm}$. Lasing was observed up to temperatures as high as $50^{\circ} \mathrm{C}$. The lasing characteristics (output powers and a typical optical spectrum) are shown in Fig. 6. The pumping threshold was close to $2 \mathrm{~W}$ near room temperature. 


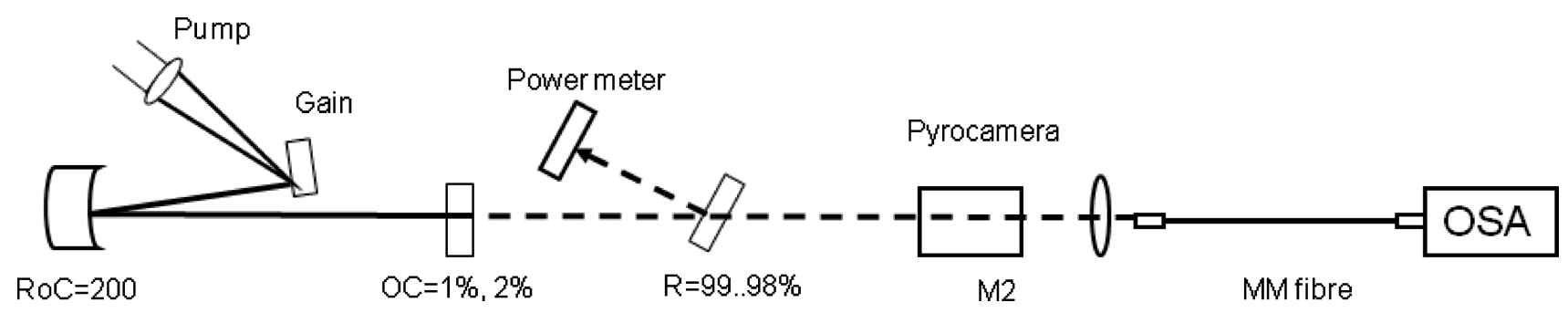

Fig. 5. Measurement set-up for the VECSEL ( $O S A$ stands for optical spectrum analyzer, $R o C$ radius of curvature, $M M$ multimode).



Fig. 6. Light output characteristics of the VECSEL at different mount temperatures, given as a function of incident $980 \mathrm{~nm}$ pump power. About $12 \%$ of the pump was reflected from the sample. The reflected power is not taken into account in this graph. Inset: typical laser spectrum.

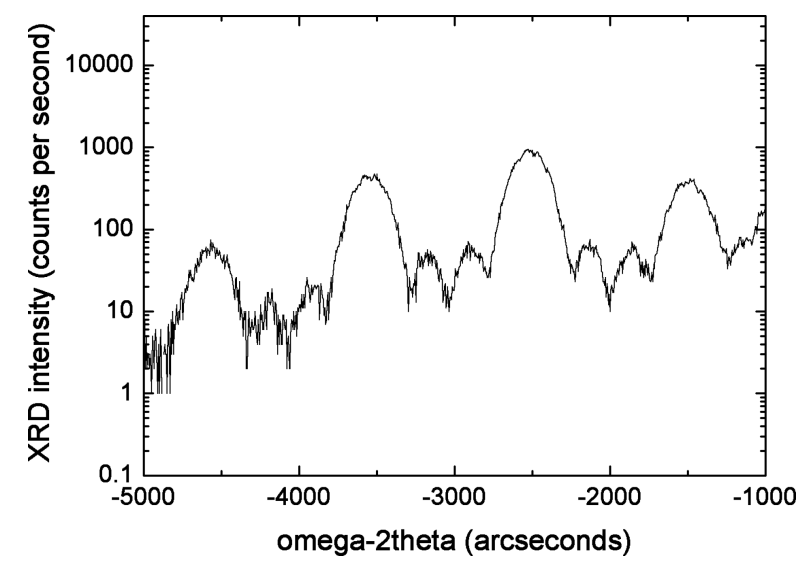

Fig. 7. XRD rocking curve, showing the QWs. The wells are clearly distinguishable, which is further evidence that the active region of the SESAM is of high crystalline quality.

\section{Experimental results and discussion: SESAM}

After the growth, the low-intensity reflectivity was measured from the SESAM, shown in Fig. 3 together with the simulated reflectivity. The differences between the simulated and measured reflectivity are caused by inaccuracies during the growth process and in the used refractive indices, together with the fact that the absorp-



Fig. 8. Nonlinear reflectivity curve for a 15-QW GaSb-based SESAM at the resonant wavelength [10].

tion of the QWs was not taken into account in the simulation. The crystal quality of the fabricated SESAM was examined by X-ray diffraction (XRD). The rocking curve shown in Fig. 7 displays the crystal peaks from the QWs. The smoothness of the curve indicates high crystalline quality of the structure. The XRD measurement was also compared to an XRD simulation. The RADS Mercury simulation software fitted the initial structure to the measured curve, and this procedure allowed us to determine how closely the actual QW thickness and indium composition matched the targeted ones. This simulation showed the $\mathrm{QW}$ thicknesses were $(8.0 \pm 0.2) \mathrm{nm}$ and the In-composition $(22.0 \pm 0.5) \%$, allowing us to conclude that the active region growth was successful.

Nonlinear reflectivity was not measured from this particular sample, but Fig. 8 reveals the typical nonlinear reflectivity behaviour for a multi-QW GaSb-based SESAM operating near the resonant wavelength [10]. The saturation fluence is similar to GaAs- or InP-based devices and has a value of about $50-60 \mu \mathrm{J} / \mathrm{cm}^{2}$.

\section{SESAM for Q-switching}

The SESAM was used to passively Q-switch a $2 \mu \mathrm{m}$ $\mathrm{Tm}^{3+}, \mathrm{Ho}^{3+}$-doped all-fibre laser. A schematic of the 


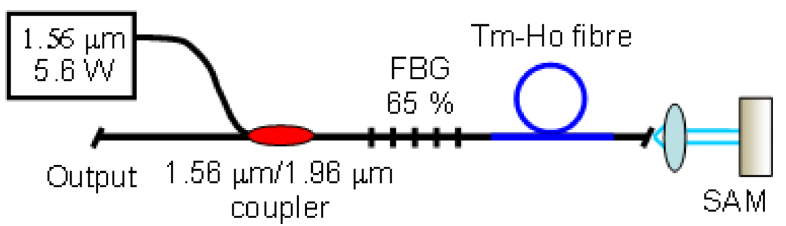

Fig. 9. Schematic of the passively Q-switched fibre laser using the GaSb SESAM.

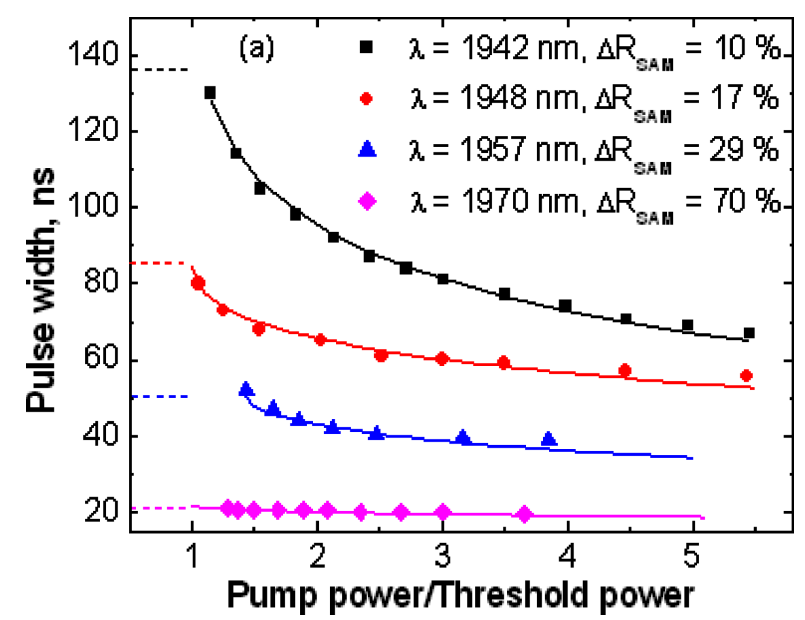

Fig. 10. The effect of the pump power and operation wavelength on the pulse width.

set-up is shown in Fig. 9. The laser was core-pumped with a $1.56 \mu \mathrm{m}$ single-mode $\mathrm{Er}^{3+}$-doped fibre laser and the Tm-Ho active fibre was placed between the GaSb SESAM and a 65\% reflective fibre Bragg grating (FBG). Four separate FBGs with different wavelengths were used to study the modulation depth's effect on the pulse width. These wavelengths were 1942, 1948,1957 , and $1970 \mathrm{~nm}$, of which the last one was for full resonant operation, with the SESAM having a 70\% modulation depth for this wavelength. The other wavelengths were for off-resonance operation, but were still affected by the resonance dip so that each of these wavelengths represented different modulation depths for the SESAM. It was observed that the larger the modulation depth, the shorter the pulse width, and also the less the pulse width depended on the pump power. The pulse widths at different operation wavelengths are presented in Fig. 10 as a function of the pump power.

\section{Conclusions}

We have studied the lasing characteristics of highpower GaSb-based VECSEL. Using a gain mirror com- prised of $\operatorname{In}_{0.2} \mathrm{Ga}_{0.8} \mathrm{Sb} / \mathrm{GaSb}$ quantum wells, we attained multi-watt output power room temperature operation. We also fabricated successfully a highly nonlinear GaSb-based $2 \mu \mathrm{m}$ SESAM with high crystal quality. The effectiveness of the GaSb/AlAsSb DBR configuration and the undemanding growth of InGaSb quantum wells make GaSb an attractive material for use in both active and passive vertical-cavity devices operating at wavelengths of $2 \mu \mathrm{m}$ and beyond. The highly nonlinear reflectivity achieved in this particular absorber mirror proved to have a significant impact on pulse shortening when the SESAM was used to passively Q-switch a $2 \mu \mathrm{m} \mathrm{Tm}^{3+}-/ \mathrm{Ho}^{3+}$-doped all-fibre laser. Our demonstration of the passive Q-switching paves the way for further development of highly nonlinear GaSbbased SESAMs with operation wavelengths extending to above $3 \mu \mathrm{m}$.

\section{References}

[1] T. Bleuel, M. Müller, and A. Forchel, IEEE Photon. Technol. Lett. 13, 553 (2001).

[2] P. Werle, Spectrochim. Acta A 54, 197 (1998).

[3] Solid-State Mid-Infrared Laser Sources, Topics in Applied Physics 89, eds. I.T. Sorokina and K.L. Vodopyanov (Springer-Verlag, Berlin, Heidelberg, 2003).

[4] H.K. Choi, J.N. Walpole, G.W. Turner, M.K. Connors, L.J. Missaggia, and M.J. Manfra, IEEE Photon. Technol. Lett. 10, 938 (1998).

[5] A. Härkönen, M. Guina, O. Okhotnikov, K. Rößner, M. Hümmer, T. Lehnhardt, M. Müller, A. Forchel, and M. Fischer, Opt. Express 14, 6479 (2006).

[6] L. Fan, M. Fallahi, J.T. Murray, R. Bedford, Y. Kaneda, A.R. Zakharian, J. Hader, J.V. Moloney, W. Stolz, and S.W. Koch, Appl. Phys. Lett. 88, 021105 (2006).

[7] J.-M. Hopkins, N. Hempler, B. Rösener, N. Schulz, M. Rattunde, C. Manz, K. Köhler, J. Wagner, and D. Burns, Opt. Lett. 33, 201 (2008).

[8] U. Keller, K.J. Weingarten, F.X. Kärtner, D. Kopf, B. Braun, I.D. Jung, R. Fluck, C. Hönninger, N. Matuschek, and J. Aus der Au, IEEE J. Sel. Topics Quantum Electron. 2, 435 (1996).

[9] A.J. Kemp, G.J. Valentine, J.-M. Hopkins, J.E. Hastie, S.A. Smith, S. Calvez, M.D. Dawson, and D. Burns, IEEE J. Quantum Electron. 41, 148 (2005).

[10] S. Kivistö, T. Hakulinen, M. Guina, and O.G. Okhotnikov, IEEE Photon. Technol. Lett. 19, 934 (2007). 


\title{
HETEROSTRUKTŪROS IŠ GaSb, SKIRTOS DIDELĖS GALIOS IMPULSINIAMS LAZERIAMS
}

\author{
J. Paajaste ${ }^{\text {a }}$, S. Suomalainen ${ }^{\text {a }}$, R. Koskinen ${ }^{\text {a }}$, A. Härkönen ${ }^{\text {a }}$, S. Kivistö ${ }^{\text {a }}$, M. Guina ${ }^{\text {a }}$,, O.G. Okhotnikov ${ }^{\text {a }}$ \\ M. Pessa ${ }^{a}$ \\ ${ }^{\text {a }}$ Tamperès technologijos universiteto Optoelektronikos moksliniu tyrimu centras, Tamperè, Suomija \\ ${ }^{\mathrm{b}}$ RefleKron Ltd, Tamperè, Suomija
}

\section{Santrauka}

Tyrinèti monolitiškai auginti iš GaSb heterolazeriai su vertikaliu rezonatoriumi. Pirmiausia pristatome GaSb pagrindu sukurtą optiškai kaupinamą vertikaliai spinduliuojančio paviršiaus lazerị su išoriniu rezonatoriumi (angl. jo trumpinys OP-VECSEL), kurio spinduliuote yra daugiavatė. VECSEL stiprinantysis darinys iš $15 \mathrm{In}_{0,2} \mathrm{Ga}_{0,8} \mathrm{Sb}$ kvantinių šulinių, užaugintų ant (100) orientacijos GaSb pagrindo su $n$ priemaiša, kambario temperatūroje generavo didesnę nei $4 \mathrm{~W}$ išvadinę galią, esant $1970 \mathrm{~nm}$ bangos ilgiui.
Lazerinis generavimas stebėtas net kai laikiklio temperatūra siekè $50{ }^{\circ} \mathrm{C}$. Taip pat pateikiame puslaidininkini isisotinantiji sugeriantiji veidrodi (angl. tokio veidrodžio trumpinys SESAM), užaugintą iš $\mathrm{GaSb}$ ir veikianti $2 \mu \mathrm{m}$ srityje. Trumpiesiems lazerio impulsams generuoti SESAM tipo veidrodis buvo kruopščiai projektuotas, kad turètų didelį moduliacijos gylị. Jis buvo sèkmingai panaudotas šviesolaidinio lazerio su $\mathrm{Tm}^{3+} / \mathrm{Ho}^{3+}$ priemaišomis pasyviai kokybès moduliacijai $2 \mu \mathrm{m}$ srityje. Gauti rekordiškai trumpi, t. y. apie $20 \mathrm{~ns}$ trukmès, milžiniški impulsai. 